\title{
Equality in Asia-Pacific: Reality or a Contradiction in Terms? - An Introduction
}

\author{
PHIL C. W. CHAN \\ Visiting Scholar/Visiting Professor, Faculty of Law, Common Law Section, University of Ottawa \\ Visiting Scholar, Institute of Chinese Studies, University of Heidelberg
}

The Holocaust brought to the fore consequences of oppressing individuals and groups by virtue of their respective particular personal characteristics, and of ignoring such oppression. Thus, in 1948, as the United Nations General Assembly proclaimed the Universal Declaration of Human Rights, since taken as largely reflecting norms of customary international law binding on all States, it was agreed by consensus in its first provision that '[a]ll human beings are born free and equal in dignity and rights. They are endowed with reason and conscience and should act towards one another in a spirit of brotherhood'.

However, notwithstanding such recognition by the international community of the importance of the right of equality in dignity and rights and its codification in numerous national and sub-national constitutions and legislation, reinforced by various multilateral and regional human rights treaties, the right of equality continues to be unable to take complete firm hold in all regions and countries. Evidence, as presented by the nine insightful papers in this Special Double Issue dedicated to exploring the place of equality in Asia-Pacific societies, suggests that although progress is being made, the right of equality has not yet fully materialised, in law or in reality, in the world's most populous region. Many factors, particularly entrenched cultural heritage and practices, the lingering effects of colonialism and newly found independence, and, above all, pervasive ignorance and prejudices, continue to impede the recognition, development and protection of equality in this region. Of course, as we begin to introduce our discussions, we by no means imply that equality, a normative right and entitlement by virtue of our humanity, has been fully achieved in societies outside the region, as it has not. Such neo-colonial thinking, as our discussions will point out, in fact perpetuates and assists in the subjugation of the right of equality in the Asia-Pacific Region. Accordingly, we hope that our discussions will also be able to shed light and generate reflections on realities outside the region as interlinked with our aim.

This Special Double Issue will begin with Clare Hemmings' 'What's in a Name? Bisexuality, Transnational Sexuality Studies and Western Colonial Legacies'. In her

Correspondence Address: Phil C. W. Chan, c/o Paul Serfaty, Asian Capital Partners, 17/F., 8 Queen's Road Central, Hong Kong. E-mail: philchan@dunelm.org.uk 
thought-provoking study exploring the role of bisexuality in transnational sexuality studies, Hemmings argues that bisexuality is either absent or inscribed as potential or behaviour, which by definition is alterable and fluctuating, rather than as a stable inborn identity, so much so that lesbians and gay men are considered the only proper subjects of sexuality studies and of sexuality discrimination and prejudices. 'The conceptualisation of bisexuality as potential', the author argues, 'refers not only to the development of individuals, but also to the relations between societies within colonialism'. Its absence or subordinated role in Western queer discourse on account of its behavioural primitivity thus reflects an equivalent and continuing Western conceptualisation of societies that have previously suffered colonisation. Such conceptualisations, as the author elaborates, perpetuate the lingering effects of colonialism in the newly independent Asia-Pacific (and African) countries and assist the notion that homosexuality is a Western/imported identity and behaviour and HIV/AIDS a Western/imported disease, hindering sexuality equality protection as well as sexual health measures. In the process, both heterosexual men and heterosexual women are also endangered, with the enforced masculinity - which subjects heterosexual men to constant and pervasive guards and attacks of their heterosexual identity and heterosexual women to domestic violence, as Phil C. W. Chan and Cecilia Milwertz and Wei Bu will discuss in their respective papers to follow - that ensues.

Phil C. W. Chan, then, in his comprehensive 'Same-Sex Marriage/Constitutionalism and their Centrality to Equality Rights in Hong Kong: A Comparative-Socio-Legal Appraisal', refutes the notion that homosexuality and protection of sexual minorities, including recognition of the right of a person to marry another person of the same sex, are Western concepts inapplicable in Hong Kong, a conservative Confucian society. Rather, Chan argues that it was the classification of homosexuality as criminal and the higher age of consent for anal intercourse and sexual intimacy between men, since ruled by Hong Kong courts as constituting discrimination on grounds of sexual orientation and thus unconstitutional, that were Western imports through Great Britain's colonisation of Hong Kong. Adopting a comparative and socio-legal approach, the author discusses the evolution of homosexuality in law from a sin to a capital crime and finally to a personal characteristic entitled to and warranting equal protection, in jurisdictions including the United Kingdom, the United States, Canada, South Africa, and Ireland as well as under various multilateral and regional human rights agreements such as the International Covenant on Civil and Political Rights and the European Convention on Human Rights. The author elucidates the unique circumstances, including two scandals and ultimately a tragedy in far-flung Beijing, that changed the status of homosexuality from being a crime punishable by life imprisonment in all circumstances, to one permissible if engaged in by two parties both aged 21 or above and invisible to others, to a personal characteristic on par with heterosexuality and constitutionally protected against discrimination. The author proceeds to explain that recognition in Hong Kong of a right to samesex marriage is not constrained by a Chinese/Confucian culture; same-sex marriage, and not just same-sex civil partnership, is in fact essential both for its own sake and for the protection of everyone, and that cultural relativist arguments against full and complete sexual orientation equality are misguided and fall prey to the conceptualisations which Clare Hemmings has dissected. In doing so, Chan also questions the place of Christianity and the Bible in Hong Kong society and dissects those verses in the Bible on which opponents of homosexuality and sexual minority rights rely. Then, referring to debates on the issue and on judicial activism in academia and in legislatures and the courtrooms 
in various jurisdictions, Chan maintains that recognition of the right of a person to marry another person of the same sex constitutes a constitutional and democratic requirement which an impartial and responsible judiciary must uphold. Finally, the author concludes with an analysis of Hong Kong's international treaty obligations in relation to same-sex marriage and to active protection of the right of equality of all persons, irrespective of their sexual orientations, within its jurisdiction.

Oppression of homosexuality and sexual minorities, as it originated from Henry VIII's Buggery Act 1533, is, expectedly, present also in countries settled primarily by those sailing from Great Britain, with New Zealand and Australia being two examples. In his 'Changing Times, Changing Minds, Changing Laws - Sexual Orientation and New Zealand Law, 1960 to 2005', Paul Rishworth lucidly traces the legal developments on homosexuality and sexual orientation equality in New Zealand. His paper illustrates both that homosexuality and sexual minorities had until the mid-1980s been treated, both in law and in reality, as an aberration, and that it was thanks to generation of knowledge that in New Zealand, as in Hong Kong and other former colonies, lesbians and gay men have now finally freed themselves from legal discrimination. Reasoning that 'a human rights culture is the best protection of rights from infringement', the author elucidates recent developments in New Zealand recognising same-sex (and different-sex) relationships as civil unions, with similar rights and obligations as are owed through marriage, and banning hate speech attributable to sexual orientation as well as other personal characteristics, and discusses the impact of sexual orientation equality and non-discrimination rights on religious institutions in New Zealand.

Same-sex marriage, of course, may not be the desired outcome for every lesbian or gay man. In her interesting 'The Same-Sex Marriage Debate in Australia', Kristen Walker argues that the institution of marriage is an inherently heterosexist and heterosexualising mechanism by which, if available to same-sex couples, members of sexual minorities will be judged and into which their freedom to engage in relations as lesbians and gay men will be subjugated. Walker's position is thus a good contrast and comparison with Phil C. W. Chan's, which, whilst silent on the issue of whether same-sex marriage is self-defeating for giving in to hetero-normative pressures, emphasises that it is equal access to the civil institution of marriage that is essential to the full and complete realisation of sexual orientation equality in law and in society. Before she begins her discussion on the normative implications of same-sex marriage, Walker analyses the recent amendment by the federal Parliament in Australia to federal marriage law in response to constitutional litigation which sought that same-sex marriages validly entered into in foreign jurisdictions be recognised and given effect as similarly valid in Australia, as different-sex marriages are. The author proceeds to discuss the debate against Australian constitutional jurisprudence as to the mode of interpretation - whether the intentions of the framers of the Australian Constitution or contemporary developments in law and society should control the issue of same-sex marriage - and as to whether the federal and state legislatures may enact or amend laws in order to provide for same-sex marriage. Then, Walker points out the current political climate surrounding same-sex marriage and concludes that instead of fighting for same-sex marriage, one should insist that the linkage between marriage and the state be removed and that 'a more tailored system of recognition, with a combination of presumptive recognition and a registration system for various purposes and allowing for the recognition of a more diverse range of relationship forms', such as that available in New Zealand, would be more appropriate. 
The linkage between marriage and the state, in fact, raises another significant concern, that is, domestic violence within marriage and family and the role of the state in perpetuating or preventing and punishing domestic violence, particularly in a country where a man is culturally entrenched as superior to, if not owning, his wife (and children). In their insightful 'Non-Governmental Organising for Gender Equality in China - Joining a Global Emancipatory Epistemic Community', Cecilia Milwertz and Wei Bu allude to the anti-domestic violence activism in China in the 1990s and early 2000s as a quintessential case study in examining the benefits and process which non-governmental women's rights organisations in China may gain - and have gained - through engagement with similar organisations in other countries and through a greater familiarity with global human rights norms. The authors demonstrate that instead of imposing their own beliefs and non-beliefs in relation to human rights and cultural practices which they may believe to reflect universal norms which developing and other countries may reject as neo-colonialist, developed countries stand capable of communicating global human rights norms for the recipients' own reflections and generation of knowledge. Milwertz and Bu's paper shows that in merely a decade domestic violence has been transformed from a non-issue in China to establishing women's rights as a human rights and anti-domestic violence as a health issue, in the light of prevailing global human rights norms. Such generation of knowledge, insight and perspectives on domestic violence amongst anti-domestic violence activists in China is particularly encouraging as 'the construction of new knowledge has not been imposed from without as a top-down education process but has instead been shaped by the activists themselves in the context of international interactions. They have engaged in what Jean Lave and Etienne Wenger generally regard as a situated learning process within a global community of practice, and by engaging in such processes the activists have joined a global emancipatory epistemic community'.

The development on protection of women against domestic violence, of course, must be supported and reinforced by the legal system in order to be truly and fully effective. In his comprehensive 'On China's Slow Boat to Women's Rights: Revisions to the Women's Protection Law, 2005', Michael Palmer examines the nature and significance of the recent amendment to China's Women's Protection Law to discern whether women's rights in China have been advanced or in fact continue to be stalled. In doing so, the author scrutinises the recent amendment against its predecessor as well as related Laws of the 'socialist-market' country. The author concludes that whilst the amendment suggests a growing concern on the part of the state with the protection of equality between men and women and of women's rights and interests in se, its tendency 'to mandate people on what not to do, rather than to lay the foundations for positive conduct and thinking by, for example, providing detailed actionable provisions, ensuring women a much greater role in public life, and promoting enthusiastically the rights of women to educational benefits'. Thus, protection of women in China continues to suffer cultural and state resistance and the progress as manifested in the amendments reveals that full and complete realisation of women's rights and interests, including their right of equality, in se in China remains a long and intricate struggle.

As abuse and disadvantages travel across generations, it is essential that we remedy and prevent inequalities as soon as, if not before, they are revealed. In his empirical 'Inequality of Educational Opportunity in Korea by Gender, Socio-Economic Background, and Family Structure', Hyunjoon Park, using comparative statistics and data, discusses the 
degree of and trend in inequality of educational opportunity in South Korea caused by South Korean children's personal and ascribed characteristics including their respective genders, socio-economic backgrounds, and the structures of their families - specifically as to whether they reside in a nuclear family or in a single-parent family and if so whether the single parenthood was caused by parental divorce or death. In addition, the author argues that recent demographic changes in South Korea brought about by a rising prevalence of marriages between Koreans and foreigners in South Korea, a country that regards itself as ethnically and culturally homogenous, will constitute a significant variable in children's educational achievement and attainment unless perceptions of ethnic and cultural homogeneity are altered.

Then, returning to Hong Kong, our attention shifts to the courtroom and the legal process itself. Whilst Hong Kong is now part of China, enjoying a high degree of autonomy, English continues to be the lingua franca of education, commence, and the legal process, with the common law legal system constitutionally preserved. In the process, however, the Chinese language (Cantonese) continues to be subjugated in Hong Kong's judicial and legal practice, even though since 1 July 1997 it is constitutionally and by legislation recognised as an official language in the former British colony. In Re Cheng Kai Nam Gary, the defendant, facing trial which might, and ultimately did, lead to his imprisonment, sought that the judge presiding over his trial be able to directly understand Chinese, with which he self-identified most intimately. His application for leave to apply for judicial review was, nonetheless, rejected. Adopting a comparative approach by reference to and scrutinising Canadian, Irish, and international jurisprudence, Phil C. W. Chan, in his 'Official Languages and Bilingualism in the Courtroom: Hong Kong, Canada, the Republic of Ireland, and International Law', argues that an individual is entitled to choose to use an official language with which he or she self-identifies most intimately in judicial services or proceedings affecting his or her rights and interests. Such entitlement, the author maintains, stems from an individual's language use rights and right to a fair trial. Furthermore, the author insists, one's fluency in the dominant official language and availability of interpretation during the relevant proceedings are immaterial and do not affect the individual's aforementioned rights. The author concludes that the unfortunate outcome and reasoning in Re Cheng Kai Nam Gary illuminated that the adverse effects of colonialism, which has long been recognised as causing and perpetuating inequalities, continue, in colonialism's altered neo-colonial ego, to be pervasive in postcolonial Hong Kong.

Finally, we conclude our Special Double Issue on equality in Asia-Pacific with Jill Cottrell and Yash Ghai's 'Constitutionalising Affirmative Action in the Fiji Islands' to reflect on whether affirmative action, whereby historically disadvantaged groups are given discriminatorily positive rights, benefits or advantages in order to redress their past disadvantages and assist them in advancing economically, socially and politically, is suitable, appropriate and effective in achieving full and complete realisation of the right of equality or merely causes and perpetuates existing inequalities only that the identities of the victims are reversed. In their reflective paper, Cottrell and Ghai, with their hands-on experience in the constitution-making process in Fiji, argue that Fiji's constitutional provision for affirmative action programmes in fact merely strengthen the existing dominant position of ethnic Fijians which the Fijian government claims to have been disadvantaged by ethnic Indo-Fijians who descend from those emigrating from India - then also under British control - to Fiji during Great Britain's colonisation, at the expense of 
Indo-Fijians. In the meantime, groups historically disadvantaged in Fiji other than for reason of ethnicity receive little or, in the case of sexual minorities, no attention from the Fijian government under the constitutional provision. In addition, the criteria for eligibility for and the standards of affirmative action programmes in Fiji have largely been indeterminate or contradictory - or in fact unconstitutional - and the implementation of these programmes faulty or ineffective, and the end result has so far been that resentment, and not equity, has grown within all sectors of Fijian Islands society. Such resentment culminated in four military coups in Fiji, with the latest one in December 2006. The core of the problem, the authors discern, lies at the heart of Fijian Islands society: 'can Fijian values, society and tradition (or perhaps a parody of tradition) be preserved, and how far are they compatible with market economy, globalisation and individualism?' The dilemma, it ought to be noted, inheres in all societies, in and beyond the Fiji Islands and the Asia-Pacific Region.

These nine critical analyses on issues of equality and inequalities in the Asia-Pacific Region, on subject matters that have not been adequately addressed either in other forums or at all, should therefore be able to provide important insight into the process of development of a person's right of equality as guaranteed in Article 1 of the Universal Declaration of Human Rights in this most populous and yet ethnically and culturally diverse region of the world, and into whether or not it has materialised and how it has been implemented or violated. However, we are conscious that our undertaking may be critiqued, in at least three respects. We are, first and foremost, conscious that this forum has not the benefit of analyses on the religious inequalities and conflicts in Thailand between the majority Buddhist population and minority Muslims and in the Philippines between majority Roman Catholics and minority Muslims, matters of great consequence not only to the guarantee of equality to take firm hold in Asia-Pacific but also to peace and stability in the respective countries and the region. We have also been unable to have the ethnic and religious minorities in China addressed in our forum. Japan's wealth, also, cannot disguise and certainly does not excuse its continuing discriminatory treatment of foreigners and Korean-Japanese persons. In addition, during our preparations we have been alerted to the religious genocide in Bhutan, a Buddhist country that prides itself on its 'Gross National Happiness', and the resulting plight of Hindu refugees in neighbouring Nepal; however, on account of time constraints we were unable to include an expert discussion on the subject. Accordingly, we urge that experts in these fields continue their essential research and cordially encourage these experts to consider submitting their important works to our Journal.

Also, we are conscious that by devoting substantial attention to issues relating to sexuality and gender equality, this forum may be perceived as having a sexuality/ gender agenda and our focus as not being evenly balanced. However, whilst such an agenda was not initially in mind, we can only be delighted with the resulting dialogues on sexuality and gender equality issues as they pertain to the Asia-Pacific Region, particularly as they are reinforced by discussions on the implications of post- and neocolonialism, manifestations of continuing grave inequalities, that inhere in the region. Furthermore, given the continuing dearth of discussions on sexuality and gender equality issues, often perceived to be of concern only to Western countries, in and by the AsiaPacific Region, we are proud in serving as host to six scholarly discussions on what sexualities actually are, the roles of sexualities in Asia-Pacific societies and of Western and former colonial countries in their being oppressed and empowered in the Asia-Pacific 
Region, and their correlation with and contribution to a person's right of equality and the development and well-being of society.

The third critique that we may envisage may, perhaps, go directly to the title of the Special Double Issue itself, that equality and Asia-Pacific cannot be a contradiction in terms. We certainly hope that they cannot, and there is only one way to find out through informed and constructive dialogues had in, and hopefully opened up by, this forum amongst others, and through the necessary legal reform and generation and dissemination of knowledge and insight to which we hope to serve an authoritative contribution.

\section{Acknowledgements}

Its planning, preparation and production spanning more than two years, this Special Double Issue would not have materialised but for the insightful contributions by the leading scholars in the fields, and I am honoured to be responsible for their general well-being. I am grateful to Frank Barnaby, Editor of the Journal, for engaging me in such an invaluable undertaking and to Taylor \& Francis, in particular Caroline Broughton, Amber Bulkley, Sarah Elvins, and especially Josephine Oakley, for their enthusiastic support of the project. I thank consultancy firm Yenji Limited for its generous financial assistance to my ongoing research and editorial work. I also thank the British Institute of International and Comparative Law, the Gender, Sexuality and Law Research Group at Keele University School of Law, the Lauterpacht Research Centre for International Law at the University of Cambridge, and the Asia-Pacific College of Diplomacy at the Australian National University for welcoming me, respectively, as Visiting Fellow during which this Special Double Issue was substantially prepared. Special thanks also extend to the ANU College of Law and the Centre for International and Public Law at the Australian National University for welcoming me as their unofficial visitor during the final stage of preparation, from which it benefited greatly. Last but not least, I thank all the anonymous reviewers who so kindly volunteered their valuable time to enable this Special Double Issue to be an authoritative source of analyses on issues of equality and inequalities as they pertain to the Asia-Pacific Region.

In the course of the years, I have had the good fortune to make the acquaintance of many amazing individuals who have helped me one way or the other in my transition through adolescence as a person and as an academic, and I must selfishly take this opportunity to express my gratitude to these individuals without whom I would not have been able to have a life and academic career with its share of joy and despair: Jon Austin, principal of Imperial College Toronto, for completely changing my life as he guided me with indescribable kindness and patience through from a Form 4 secondary school student from Hong Kong with a gloomy academic future to someone offered law school admissions in an amazing five months (under circumstances and with memories I would not wish to relive but which I will forever cherish); Sylvia Acevedo, Professor Andrew Byrnes, Professor Johannes Chan, Robin Corcos, John Harris, and Robert Morgan for their kindness and patience in helping me survive law school and Professor Andrew Byrnes, Jill Cottrell, and Donald Lewis for introducing me to legal research and writing with which I am since ever preoccupied; Dapo Akande for his model of academic qualities and his continuing support to my academic endeavours and Alisoun Roberts for helping me withstand the Durham winter and other matters of concern; and Jon Austin, Anita and Terry in Hamilton, 
Sylvia Acevedo, Robin Corcos, Jill Cottrell, Michelle Chong, Sarah Gardiner, Monica Hall, Juyon Kim, Julie Wong, Detlev Pusch, Tamara McKen, Marianne in Berlin, Alisoun Roberts, Linn Edvartsen, Felizmina Lutucuta, Aisling O'Sullivan, Sarah Wennberg, Richard Gardiner, Philip Ridgway, Linda Christie, Annalisa Meloni, Nicky Priaulx, and Mark Nolan for tolerating my many flaws and extending to me their warmest company and friendships and the many wonderful and cherished memories. I wish also to thank the staff and students at St. Stephen's College (Stanley), Hong Kong, for showing me the need and fostering in me the resolve and resiliency to strive to be a kind and truthful person in spite and because of ignorance, prejudice, oppression, and, above all, self-enforced silence, and Au Tak-ming at my primary school (which was not so long ago) for giving me opportunities for responsibility and a sense of purpose. Above all, I am grateful to my mother and my grandmother, who gave me as best they could the opportunities that had been denied them, and Paul Serfaty, with his years of unquestioning confidence, unreasonable dedication, wonderful company, intelligent conversations, and love. 